\title{
Cosmopolitan Identity - historical origins and contemporary relevance
}

\author{
Marin Beroš
}

Review article

UDK 172.1(093)

$316.75^{\prime \prime} 19 / 20 "$

\begin{abstract}
The idea of cosmopolitanism owes its origin to the Cynic Diogenes of Sinope, who first proclaimed, "I am cosmopolitan!" Although this identification was primarily negative in the sense that he did not declare it with the intention of becoming the first "citizen of the world" but rather to express disagreement with the laws of the ancient poleis, the Stoic school had consequently taken his initial idea and turned it into a comprehensive concept: the unity of humanity based on the shared ability to reason. At the beginning of the $21^{\text {st }}$ century, this ancient idea is deemed a well-known concept. Indeed, cosmopolitanism is today primarily regarded as a specific idea, or behavioural pattern, represented by cosmopolitans or citizens of the world. Cosmopolitans, in turn, are those who consider themselves unfettered by the boundaries of existing political communities and their loyalty is not to any particular political community, rather they owe their loyalty to the more universal community of all human beings. By itself, this definition is accurate, but it is also too narrow, because the cosmopolitan idea involves so much more. From its former definition as mere detachment from the political systems of nation states and as the notion of "openness to the world", cosmopolitanism is now beginning to be seen as a legal and political framework, as an ethical ideal and vision of justice, as well as a type of identity choice made by individuals. This essay will try to demonstrate that what all of these different contemporary views on cosmopolitanism share is a vision of social belonging that cuts across the political boundaries imposed upon us, as well as a construction of new cosmopolitan identities that have just begun to erode our current understanding of the political community.
\end{abstract}

Keywords: cosmopolitanism, cultural cosmopolitanism, cosmopolitan identity, nationalism 
If we intend to elaborate on what cosmopolitan identity is, perhaps the best way is to start with the related question: what is cosmopolitanism? Most people will agree that cosmopolitanism is a specific idea, or behavioural pattern, represented by cosmopolitans or citizens of the world. Cosmopolitans are, in turn, those who consider themselves unfettered by the boundaries of existing political communities and their loyalty is not to any particular political community, whether it is a community of birth or one of choice, as they owe their loyalty to the more universal community of all human beings. This definition is accurate, but it is also too narrow, because the cosmopolitan idea as we recognize it today involves so much more. Contemporary cosmopolitanism is, due to its historical development, a composite idea, formed from several related subordinate ideas, which also enhances its ambiguity as a whole. From its former definition as mere detachment from the political systems of nation states and as the notion of "openness to the world", cosmopolitanism is now beginning to be seen as a legal and political framework, as an ethical ideal and vision of justice, as well as a type of identity choice made by individuals.

The very idea of cosmopolitanism owes its origin to the Cynic Diogenes of Sinope, who first proclaimed "I am cosmopolitan!" (Diogenes Laertius 1925: VI 63). This identification was primarily negative in the sense that he did not declare it with the intention of becoming the first citizen of the world but to express disagreement with the laws of the ancient poleis that he did not want to obey. Nevertheless, that original notion was soon about to change. The Stoic philosophical school took his initial idea and turned it into a positive concept, greatly related with their teachings on the cosmopolis: a city inhabited by the wise and the gods. Based on the preserved fragments of his teachings, it seems that the originator of the school, Zeno of Citium, did actually not advocate cosmopolitanism. He did propose the concept of an ideal city similar to Plato's, but the doctrine of the cosmopolis, which will prove to be significant for the development of cosmopolitanism, was devised by his pupil Chrysippus. He presumed that since all human beings (along with the gods) are citizens of the cosmopolis due to their possession of reason whereby they understand the true law, it follows that we should look upon other human beings with affinity, as they all belong to us. This human unity in reason forms the basis of the Stoic cosmopolitanism. The subsequent development of the Stoic school adapted this basic ethical idea to the political demands of the time. Gradually, the idea of the fellowship of humanity based on their rationality transformed under the influence of the later Stoic authors such as Cicero into ius gentium, the law that 
regulates relations between imperial subjects. Although modified, the Stoic idea of human unity in the later, Roman period, after coming into contact with Jewish mysticism, had a profound impact on an emerging religion: Christianity. Its concept of human dignity had long-lasting consequences on European society, which would eventually culminate in the global recognition of human rights in the $20^{\text {th }}$ century, embodied in the United Nations Universal Declaration of Human Rights in 1948.

This initial development of the idea of cosmopolitanism was followed by a period of "dormancy" for this theme, which to a certain degree endured until the $18^{\text {th }}$ century. Nevertheless, it is difficult to assert that there were no developments connected to the cosmopolitan idea during this long period. De monarchia, a text in Latin by Dante Alighieri from the $14^{\text {th }}$ century was one. In it, Dante confronted the political problems of his times, and in the interest of peace advocated a universal monarchy, a sort of precursor to today's proposals for global governance. Another development in this regard consisted of the works of Erasmus of Rotterdam, who in $16^{\text {th }}$ century built on the teachings of Stoic cosmopolitanism to advocate the idea of world peace. Moreover, in the $17^{\text {th }}$ century, Hugo Grotius, extrapolating from the theory of natural rights, first formulated the idea of the rights that an individual has simply by being a human. Although all their works undoubtedly had influence on what we today consider "cosmopolitanism", the term did not resurface until the Enlightenment era, when interest in a number of projects on "eternal peace" emerged. The most notable were those formulated by Abbé de Saint-Pierre, Jean-Jacques Rousseau and Jeremy Bentham, and of course, the most renowned by Immanuel Kant. Kant's essay "Perpetual Peace" (Kant, 1991) is his strongest cosmopolitan work, but he also addressed cosmopolitanism in the essay "Idea for a Universal History with a Cosmopolitan Purpose" (Kant, 1991), as well as in certain parts of The Metaphysics of Morals (Kant, 1996). In "Perpetual Peace", Kant offered six preliminary articles, such as the abolition of standing armies or non-interference in the internal affairs of other states, that aspired to reduce the likelihood of war, but on their own they could not establish a lasting peace, and three definite articles, which would in turn lead to lasting peace. These three articles are that every country should have a republican constitution, that every country should participate in the foedus pacificum and that cosmopolitan right formulated on the basis of general hospitality must be instituted. The alliance of states that Kant proposed should be a voluntary coalition, whose main purpose is securing world peace that is conducive to the achievement of all inherent human capabilities. 
This period is also significant for our central theme: cosmopolitan identity. During the Enlightenment, the idea of nationalism and the related idea of the nation state rose to prominence, and they both still have significant impact on how we understand our identity today. Nationalism, although long considered strictly opposed to cosmopolitanism (especially in the $20^{\text {th }}$ century), actually shares many similarities with the latter. Both concepts were subject to considerable scientific interest in the $18^{\text {th }}$ century. Early nationalism, particularly evident in writings of Johann Gottfried Herder, was notably aligned with the Enlightenment (Herder 2002). Although Herder advocated the separation of nations as a prerequisite for the development of the individual, he also advocated the equality and unity of the human race. All this suggests that the idea of nationalism was built on the premises of the cosmopolitanism, although the reverse also seems to be true. The concept of the nation is in its intention cosmopolitan, as it aims to unite the various peoples around one universal institution: the republic. Discourse during the Enlightenment period differed only in the spatial character of the republic, that is, whether it should be local or universal. Although this type of "general nationalism" died out by the beginning of the twentieth century, in the last twenty years we have seen a revitalization of the idea in cosmopolitan discourse through graded forms of cosmopolitanism.

It is also important to mention another influence on our contemporary understanding of cosmopolitanism which came to the prominence in the $19^{\text {th }}$ century through the works of Karl Marx and Friedrich Engels. In The Communist Manifesto, they stated that the worker has no homeland (Marx et al. 1972). Since capital also has no homeland but travels wherever it may generate profits, the proletariat cannot afford to have the same. As the proletariat is defined by the lack of ownership of its members, it literally has no stake in the state, which has become an instrument for maintaining the bourgeois rule. Their rallying cry for the transfer of conflict from state borders to class boundaries strongly resembles Diogenes' antinomic statement that he does not have polis, but rather that his polis is the cosmos. It is clear that the cosmopolitanism advocated by Marx and Engels had a limited character and served a specific purpose. Indeed, they do not they call him such, but they used the term internationalism, while cosmopolitanism remained in the pejorative sense, something that belongs to the opposing camp, the bourgeoisie. Simultaneously, as much as they were suspicious of cosmopolitanism, Marx and Engels held that the proletariat shares common interests everywhere, and that the goal of the communist movement they endorsed is to convince the proletariat anywhere in the world that they truly 
share those interests and that they, as The Communist Manifesto in its final paragraphs so strongly urges, must unite in the revolution which will topple the capitalist order. This, together with the idea of a classless society and the anticipated withering away of the state after the revolution, also strongly implies a certain form of cosmopolitanism.

Kant's aforementioned political ideas have partly achieved their practical fulfilment in the $20^{\text {th }}$ century with the establishment of international organizations such as the League of Nations and then the United Nations. Unfortunately, though, both of these organizations have proved to be unsuccessful, especially with regard to the establishment of lasting world peace. Nevertheless, Kant's political theory proved more successful, which was particularly evident in the works of authors such as John Rawls, who was among the most prominent followers of Kantian political thought in the $20^{\text {th }}$ century. Although we cannot consider Rawls a cosmopolitan thinker, his influence on contemporary cosmopolitan theory was and still is immense. In his major work $A$ Theory of Justice, he tried to save liberalism from falling into libertarian and totalitarian traps, but in it he still did not provide a convincing framework for the global application of justice (Rawls 1999a). That limitation of $A$ Theory of Justice provoked numerous responses, from authors such as Charles Beitz (Beitz 1979), Thomas Pogge (Pogge 1989) and Brian Barry (Barry 1995), which in turn have made global justice an important issue in contemporary political philosophy. Influenced by this commentary, Rawls also joined the growing debate on global justice by expanding his theory to encompass the global community in The Law of Peoples (Rawls 1999b). In it he extended his theoretical postulates of justice formulated in A Theory of Justice, which focused on establishing a social contract that constitutes a single political community, to the community of all peoples. His basic idea was to retain the Kantian stance delineated in "Perpetual Peace" and Kant's ideas about foedus pacificum. Rawls believed that for the achievement of the idea of eternal peace we must begin with the idea of the social contract of the liberal democratic constitutional order and then expand it by introducing the second original position at a level in which the representatives of liberal peoples communicate with other liberal peoples. However, since all peoples of the world are not liberal, Rawls was willing to make certain concessions. In the law of peoples, there is a place for "well-ordered" communities, which are not liberal, but they respect basic human rights and conduct a non-aggressive foreign policy. 
Alongside Rawls, a host of other contemporary philosophers approached the topic of cosmopolitanism, but from several different positions. For example, Martha Nussbaum approached the subject from its ancient, ethical origins, and it seems that she advocates a rather strict concept of cosmopolitanism, that is, one that includes a broad range of duties to strangers (Nussbaum 2002). Kwame Anthony Appiah advocates a more realistic concept called rooted cosmopolitanism, which acknowledges our duty to help every human being, but also recognizes the priority of those that we somehow consider "closer" (Appiah, 2007a). Finally, there are authors like Daniel Archibugi (Archibugi 2002) and David Held (Held 2010) who observe cosmopolitanism from the standpoint of political theory and focus their thinking on cosmopolitan society and the cosmopolitan democracy constructed on its foundation. Even this cursory review of history and contemporary topics indicates the complexity and importance of philosophical reflections on cosmopolitanism. Moreover, in the last three decades, we have witnessed the scholarly revival of the subject, not just in philosophy, but also in sociology, political theory, anthropology and cultural studies. It seems that this revival has a strong connection with the synchronous emergence of globalization theory, which searched for an elaboration of globalization processes that have not only made our world more connected, but have also made us more aware of that fact.

This thematic diversity points to a few things. The first is the complexity of contemporary cosmopolitan phenomena, because even among authors who come from closely-related scholarly circles there are significant discrepancies in the understanding of cosmopolitanism as a whole. The second, and closely related, is that the boundary between the basic conceptual units within the idea of cosmopolitanism is not always clearly marked, which is another fact in favour of the uniqueness of the idea, despite its still high degree of heterogeneity. Third, this is only a small sampling of authors in the humanities and the social sciences who deal with the idea of cosmopolitanism. Given that cosmopolitanism, due to the effects of ongoing globalization processes, is a doctrine in a state of change, it is still theoretically "uncharted territory", and in turn, with the further development of these same processes, cosmopolitan theory will gain increasing importance.

For our theme, it is important to note that the mode that is concerned with questions of cosmopolitan identity is in the literature predominantly named cultural cosmopolitanism. Here we shall not enumerate every author that uses this term, but we will refer to a book by Robert J. Holton, Cosmopolitanisms 
(Holton 2009), in which he diligently, in one of the appendices, provided a comprehensive list of usages of every term connected to cosmopolitanism in contemporary scholarship. Returning to the subject of cultural cosmopolitanism, it emerged as a theoretical position based on the historically long-standing practice of merging and creating new cultural patterns. At first glance, the cultural cosmopolitan position seems rather simple: all cultures are equal, and therefore they should be appreciated equally and everyone should have the same right to enjoy them. But then the question arises: what are we to do with cultures that are essentially non-egalitarian, with those that do not respect the equal rights of all individuals? What are we to do with cultures that treat genders unequally, the members of one religion different than the members of another, or treat people of different sexual orientations unequally? The conflict that arises here is the conflict between different modes of cosmopolitanism, between its ethical and cultural components, and it also reflects the conflict inherent in liberalism - between equality and autonomy - and it seems that it will not be easily, if ever, resolved.

This debate on cultural cosmopolitanism and its contradictions was initiated with the emergence of cultural studies at the end of the 1960s. Cultural studies is generally regarded as a post-modern critique with a field of research that was largely shaped by the anti-colonial, feminist and queer critiques of the "grand narratives" of the modern era. As questions of identity and its construction arose, they led to a different consideration of the relationship between the individual and the political community inside liberal societies, which for the first time formed what will be henceforth known as identity politics. The question of identity politics brought about the question of the right to culture, from which the theory and practice of multiculturalism developed.

Questions of identity are also gaining considerable attention within contemporary political theory. Because of its reliance on liberal theoretical precepts, as ideal individuals stripped of all modifiers, it has been severely upset and compelled to reassessment by questions of identity. As Kwame Anthony Appiah observed in The Ethics of Identity, there are two opposing views on the formation of our identity as individuals (Appiah 2007). The first comes from romanticism and its essence lies in seeking or finding for ourselves the meaning of life that is just waiting to be found. This view is called authenticity, and we can say that its maxim is "stay true to what you already are". The second view is an existentialist, which according to Jean-Paul Sartre's phrase "existence precedes essence" claims that we have to invent ourselves out of nothing. Appiah has 
asserted that both of these views are incorrect as the authentic view denies the creativity of individuals to shape their own identity, while the other view goes to the other extreme, denying everything except creativity.

Regardless of the manner of its formation, our identity is never one-sided. It has its own individual and collective component, and with them there is, as Bhikhu Parekh claimed in A New Politics of Identity, a universal, generally human component (Parekh 2008). These three components compose an individual's identity: personal identity that is unique to the individual; social identity, which binds the individual to a particular ethnic, religious, cultural and other, similar community; and general human identity that binds him/her to all people. All of these components are intertwined and inseparable within the overall identity of the individual. Regarding Parekh's concept of identity, for cosmopolitanism in general the first and third components are not problematic, while the second, the social identity component, represents a field of conflict. If social identities and the connections made through them are exaggerated, as they are in the case of chauvinism and nationalism, then they prevent identification on the third, general human level.

In light of this, how do we explain the conflicted idea that is cultural cosmopolitanism? Due to the impact of universalism that is characteristic of cosmopolitanism in general, there are great discrepancies in the cultural cosmopolitan mode. For this reason, cultural cosmopolitanism can be divided into strict and moderate forms. The strict form of cultural cosmopolitanism sides with universalism and celebrates the mixture of cultures, and is also concerned with the protection of the rights of individuals to choose their preferred cultural patterns in the construction of their identity. This form of cultural cosmopolitanism, although it does not appear so at first glance, ultimately leads to cultural homogenization and the construction of a hybrid world culture. On the other hand, in its advocacy of particularity moderate cultural cosmopolitanism is akin to nationalism, but unlike it, it does not advocate the mandatory survival of political community, but rather the survival of cultural communities, which are seen as a source of great wealth in human lives that are erased by excessive cultural homogenization.

The aforementioned Kwame Anthony Appiah is the most prominent advocate of the more moderate version of cosmopolitanism mixed with patriotism, which he calls rooted cosmopolitanism. In his view, strict ethical cosmopolitanism that completely negates borders, which was endorsed by the Stoics, or more recently by Martha Nussbaum, is wrong, because cosmopolitan 
values seen as such are essentially only covertly imperialist. They are, according in his words "parochialism, yet again, puffed up with universalist pretensions; liberalism on safari". (Appiah 2007: 214). His proposal is therefore to change the current cosmopolitanism, and from its foundations - which are inclined toward liberal individualism - direct it into a communitarian upgrade. Such cosmopolitanism would accommodate the expression of the importance of local identities, because these same identities comply with the cosmopolitan idea that celebrates the fact that there are different, local ways of being human. Unlike humanism, which stands in the background of ethical cosmopolitanism with the intention of emphasizing equal recognition of all human beings, cultural cosmopolitanism in its moderate form depends on the existence of a multiplicity of political states as reservoirs of the cultural heterogeneity of mankind.

Significant work in diverting the focus from ethical cosmopolitan theories to the cultural cosmopolitanism is collected in Cosmopolitics: Thinking and Feeling beyond the Nation, edited by Pheng Cheah and Bruce Robbins (Cheah et al. 1998). The contributions in this book were written under the influence of the cosmopolitan shift in postcolonial theory which was intimated by the authors such as Homi Bhabha (Bhabha 1990) or James Clifford (Clifford 1988). This shift is, in contrast to earlier postcolonial theory, characterized by a celebration of hybrid culture, that is, one to the understanding of the construction of identity that we had earlier referred to as strict cultural cosmopolitanism. Also, a number of authors in this collection problematized the relationship between nationalism and cosmopolitanism and their universalistic perceptions, which created space in cosmopolitan theory for research into other forms of graded cosmopolitanism.

The essays presented in Cosmopolitics: Thinking and Feeling beyond the Nation pointed to a shift in the cosmopolitan theory in relation to the moral universalism proposed by Martha Nussbaum. However, in assessing the cosmopolitan moment, Cheah stated that the focus on hybridity should have a certain limit (Cheah et al. 1998). He warned that on the one hand the new hybrid cosmopolitanism places excessive emphasis on culture at the expense of its material basis, while on the other hand it does not realize that a large segment of cultural cosmopolitanism is nationalism in a new guise. In his later work, Cheah focused on locating cosmopolitanism inside national liberation projects that are still occurring in the former European colonies, and he adopted the view that cosmopolitanism can only be effective as an upgrade from nationalism, precisely because the standard cosmopolitan view ignores the fact that the state is a 
necessary condition for the development of individuals, which is especially tragic for those who are victims of prior global political processes (Cheah 2006).

Alongside this conflict with the strict notion of ethical cosmopolitanism, a significant determinant of cultural cosmopolitanism is the questioning of the relationship between cosmopolitan universalism and national particularism. Appiah, in his essay "Cosmopolitan Patriotism", had already pointed to the paradox in which the cosmopolitans who advocate cultural plurality could find themselves (Cheah et al. 1998). In fact, they would not be able to enjoy it if we all become citizens of the world. Therefore, in regards to the imaginary, cosmopolitan culture, all other cultures are minority cultures, and the majority of modern cosmopolitan criticism comes from its universalizing tendencies and its equalization of culture. This universalization of culture is seen in most of the world as a Western project. But what is the alternative to universalization? Fundamentalism - a fictitious return to pre-modern roots - appeared as one of the responses to this process. Is the conflict between fundamentalisms of various shapes and colours our future? Thanks to the events of September 11, 2001, our media space is saturated with stories of Islamic fundamentalism, but the Christian and Jewish counterparts can be considered just as dangerous. But the list does not stop here, because fundamentalism is obviously typical of the monotheistic religions with pretensions to a universal truth, something that is seriously challenged by the postmodern epistemological project. How are we to resolve the conflicts posed by fundamentalism? Ethical relativism does not lead to a resolution of the problem. Indeed, it is rather like a drug that is as dangerous as the disease it supposed to remedy. If none of the contenders for the truth is wrong, that does not automatically mean that they are all right. For the liberal political community, the question of religious truth should not be of primary importance, but at the same time allowing each religious practice its place in the public sphere should be considered with caution.

As Edward Said noted, the romantic conception of culture as a whole connected to the ethnic community did not applied for a long time, if it ever did. Therefore, there is no such thing as a pure culture, as all are involved with one another, they all are hybrid, heterogeneous, extremely different and nonmonolithic (Said 1994). This, as well as the identity policy questions raised earlier, was the basis for the formation of the theory, as well as practice, of contemporary multiculturalism that tries not just to protect cultures from global assimilation, but also to diminish the threat of fundamentalist cultural aberrations. 
As Mesić carefully observed in his book Multikulturalizam, today's multicultural society appeared in spite of centuries of the cultural homogenization practices of the nation state, which was precisely constituted through the destruction of traditional culture, particularly of minority communities (Mesić 2006). He continued by observing that multiculturalism has become dramatic in liberal democracies, since they have incorporated respect for diversity into the very foundation of their constitutions and laws, and made the ability to integrate diversity one of the foundations of their legitimacy and civilizational superiority. Assimilation, which used to be practically applied and theoretically rationalized as the best means for the integration of minority groups in the dominant mainstream society, is suddenly unacceptable, and apparently not effective as previously believed. Finally, he concluded that today, minority and underprivileged groups and their representatives publicly and loudly seek recognition of their differences as socially equivalent.

Mesić also observed that the scholars involved in this field usually recognize three types of multiculturalism that are evolving in our modern societies, depending on the type of groups that claim their uniqueness. The first type of multiculturalism recognizes ethno-cultural diversity, which includes indigenous peoples, national minorities, ethnic groups and immigrants. There are some claims that these differences are the only subject of multiculturalism, while the other two types of multiculturalism belong within a broader definition of social pluralism. The second type of multicultural diversity is based on sexual or gender identity, and the third on physical characteristics such as disabilities. The last two types of diversities are not widely accepted, and thus are subject to sometimes acrimonious debate about the theory and practice of multiculturalism.

Multiculturalism within political theory functions on the assumption that within the state the citizenship bond weakens as states become more multicultural or a culturally heterogeneous population becomes more aware of its diversity. As a result, the loyalty of citizens to the state is weakened in relation to the loyalty of its citizens to their ethnic or cultural group. In return, the government recognizes the need to deal with some of its citizens differently, recognizing their group rights, which violates the liberal principle that all citizens are politically equal. The project of reconciliation of cultural rights and equality within the liberal political community is therefore one that is significant for a number of political philosophers, among which the most notable is Will Kymlicka (Kymlicka 1996). 
Kymlicka also applied this particularistic view of political community to the global level. He believed that the proponents of cosmopolitanism overemphasized the effects of globalization, and that national citizenship is not weakened to such an extent that we may consider it obsolete. Nation-states are still an important place for the implementation of policies, including those concerning global questions. In addition, Kymlicka is sceptical of the idea of democratic international institutions and organizations. He finds the primary reason for this attitude in the fact that the level of connectivity between peoples at the global level is not the same as between citizens on the national level. He considers this connection unlikely, because the conditions for democratic decision-making and formation of the ideas of a common good are limited not so much by national borders, but rather by linguistic and cultural boundaries. According to him, all politics are actually a single politics in the vernacular, or local language. Therefore, the idea of cosmopolitan democracy is institutionally difficult to implement, but it is also socially unlikely (Kymlicka 2001).

Of course, there is the opposition which holds that the rights of specific cultural groups are significantly protected under civil law, and thus oppose the formation of the "special rights" which multiculturalism demands, since they are too reminiscent of the ancien régime, in which certain social groups, depending on the concept of honour, had differing degrees of civil rights. It appears that the most prominent advocate of this modern version of egalitarian liberalism was Brian Barry. Since he defended the position that the state, in order to comply with the requirements of justice, must endorse the principle of equality of opportunity, he was strictly against "special" institutions such as hospitals or schools intended exclusively for the members of certain cultures. According to his understanding, equality of opportunity exists only when the results of an action depend solely on the choices and decisions of individuals, and not on factors such as social class, race or family origin.

For this reason, in his book Culture and Equality, Barry argued that cultural and religious minorities should be held responsible for the consequences of their actions and beliefs (Barry 2000). He explained this position by comparing cultural and religious beliefs to physical defects, and claimed that the first are not limiting in a similar way as physical impairments. Physical impairments restrict individuals in circumstances that other members of society have, while cultures and religions may shape the will of the individual in relation to whether or not he or she will "jump at" a particular opportunity, they do not affect whether that opportunity exists as such. Barry therefore claimed that to achieve fairness in society it is only 
necessary to ensure a reasonable range of equal opportunities, rather than to ensure equal access to any particular choice or the result.

This overview of multiculturalism and the special rights of minority communities leads us to an interesting reversal that occurred in the positions of the political Left and Right, which was noted by the sociologist Todd Gitlin:

"Through the $19^{\text {th }}$ and $20^{\text {th }}$ centuries, the Left believed in the common human condition, and the Right in fundamental differences between classes, nations and races. The Left wanted collective acts of restoration, the Right has supported the primordial ties of tradition and community as opposition to any changes ... Today, the Right speaks the language of unity. Its rhetoric of global markets and global freedom has something of the old universalism. To be on the Left, on the other hand, means to ask if can we even talk about humanity." (Gitlin 1996:84)

Although superficially it resembles cultural cosmopolitanism, multiculturalism, which has become a popular topic for the political left in Western democracies, is in its actuality essentially different. While cosmopolitanism includes the recognition and acceptance of diversity, multiculturalism is a descendant of the eighteenth-century nationalism, the doctrine of the conservation of "perfect box" cultures intact side by side. Therefore, we should definitely take into account the criticism of advocates of multicultural policies made by Terry Eagleton, that those who perceive plurality as a value in itself are mere formalists and do not notice the amazingly imaginative variety of forms that, for example, racism can take (Eagleton 2000).

The world we know today is vastly different from the one that ancient Greeks knew. However, the concept of "citizen of the world" which was created over two thousand years ago still has not lost its importance. Nevertheless, the times have changed, and with them, it seems that we also need a new type of cosmopolitanism that will be capable of confronting all of the complexities of our globalized world. But, how should this new cosmopolitanism need to look for it to have the potential to effect significant change in our lives? Surprisingly, it need not be much different. The new cosmopolitanism should build on the cosmopolitan ideals of the Enlightenment, because they, despite considerable criticism, are still relevant to our time. The references to freedom, equality and connections between people that go beyond our local borders still resonate today. However, what the new cosmopolitanism, unlike the old, must do is to take into account and re-evaluate the normative value of nationalism, because in 
caring for the local we can learn much about caring for the global. We could, as Martha Nussbaum claimed, referring the Stoic Hierocles, expand our circle of care ever outwards (Nussbaum, 2002) Therefore, the new cosmopolitanism, though it should not forsake advocacy for the global human community, should at least try to reconcile the idea of universal human identity with the particular identities that are smaller and more specific than the human race.

\section{Bibliography}

APPIAH 2007

Kwame Anthony Appiah, Cosmopolitanism - Ethics in World of Strangers, New York 2007.

APPIAH 2007

Kwame Anthony Appiah, Ethics of Identity, Princeton, NJ 2007.

ARCHIBUGI 2003

Daniele Archibugi (ed.), Debating Cosmopolitics, London 2003.

BARRY 1995

Brian Barry, Justice as Impartiality, Oxford 1995.

BARRY 2000

Brian Barry, Culture and Equality - An Egalitarian Critique of Mullticulturalism, Cambridge 2000.

BEITZ 1979

Charles Beitz, Political Theory and International Relations, Princeton, NJ 1979.

\section{CLIFFORD 1988}

James Clifford, The Predicament of Culture: Twentieth-Century Ethnography, Literature, and Art, Boston, MA 1988.

CHEAH ET AL. 1998.

Cheah, Pheng; Robbins, Bruce (eds.), Cosmopolitics - Thinking and Feeling Beyond the Nation, Minneapolis, MN 1998.

\section{DIOGENES LAERTIUS 1925}

Diogenus Laertius, Lives of Eminent Philosophers, Boston, MA 1925.

\section{EAGLETON 2000}

Terry Eagleton, The Idea of Culture, Oxford 2000

GITLIN 1996

Todd Gitlin, The Twilight of Common Dreams - Why America is Wracked by Culture Wars, New York 1996. 
HELD 2010

David Held, Cosmopolitanism - Ideas and Realities, Cambridge 2010.

HERDER 2002

Johann Gottfried Herder, Philosophical Writings, Cambridge 2002.

HOLTON 2009

Robert J. Holton, Cosmopolitanisms - New Thinking and New Directions, New York 2009.

KANT 1991

Immanuel Kant, Political Writings, Cambridge 1991.

KANT 1996

Immanuel Kant, The Metaphysics of Morals, Cambridge 1996.

KYMLICKA 1996

Will Kymlicka, Multicultural Citizenship - A Liberal Theory of Minority Rights, Oxford 1996.

KYMLICKA 2001

Will Kymlicka, Politics in the Vernacular: Nationalism, Multiculturalism and Citizenship, Oxford 2001.

MARX ET AL. 1972.

Karl Marx, Friedrich Engels, The Communist Manifesto, Oxford 1972.

MESIĆ 2006

Milan Mesić, Multikulturalizam, Zagreb 2006.

NUSSBAUM 2002

Martha Nussbaum (ed.): For Love of Country?, Boston, MA 2002.

PAREKH 2008

Bikhu Parekh, A New Politics of Identity - Political Principles for an Interdependent World, New York 2008.

POGGE 1989

Thomas Pogge, Realizing Rawls, Ithaca, NY 1989.

RAWLS 1999a

John Rawls, A Theory of Justice - Revised Edition, Cambridge, MA 1999.

RAWLS 1999b

John Rawls, The Law of Peoples with The Idea of Public Reason Revisited, Boston, MA 1999.

SAID 1994

Edward Said, Culture and Imperialism, New York 1994. 